\title{
Hepatitis B Virus Surface Antibody
}

National Cancer Institute

\section{Source}

National Cancer Institute. Hepatitis B Virus Surface Antibody. NCI Thesaurus. Code C62796.

An antibody produced by B lymphocytes to the hepatitis B surface antigen as part of the immune response to hepatitis $B$ viral infection. 